\title{
The effect of teachers' socioeconomic status on elementary schools' life in Indonesia: An empirical study in the elementary schools of Merauke district, Papua
}

Werang, Basilius Redan

State University of Musamus [Universitas Musamus], Merauke, Indonesia (Lirang267@yahoo.co.id)

Lewaherilla, Esy D.

State University of Musamus [Universitas Musamus], Merauke, Indonesia (esyalewaherilla@gmail.com) Irianto, Okto

State University of Musamus [Universitas Musamus], Merauke, Indonesia (ovi.irianto@yahoo.com)

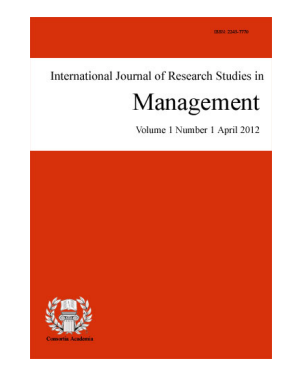

ISSN: $2243-7770$ Online ISSN: 2243-7789

OPEN ACCESS

Received: 15 October $2016 \quad$ Revised: 23 November $2016 \quad$ Accepted: 14 December 2016

Available Online: 4 January 2017 DOI: $10.5861 /$ ijrsm.2017.1657

\section{Abstract}

The role of teachers in school is of the most important resource to school effectiveness. This study was aimed at investigating the effect of teachers' socioeconomic status (SES) on school life in elementary schools of Merauke district, Papua, Indonesia. Three statements of problems guided the study, that are: (a) does teachers SES significantly effect on teachers job satisfaction in elementary schools of Merauke district, Papua, Indonesia?, (b) does teachers SES significantly effect on teachers morale in elementary schools of Merauke district, Papua, Indonesia? and (c) does teachers SES significantly effect on teachers organizational commitment in elementary schools of Merauke district, Papua, Indonesia. This study employed a quantitative approach using survey research design. A purposive sampling was used to obtain 258 respondents drawn from amongst elementary schools' teachers of Merauke district. Data were analyzed quantitatively using Statistical Package for the Social Sciences (SPSS) version 16. The study finds that overall teachers SES has a positive and significant effect on school's life, in regards to teachers job satisfaction, teachers morale, and teachers organizational commitment. These findings might be worthwhile for the government, especially government from the low-income countries, to pay more attention and to make an effort of creating different programs to enhance teachers SES.

Keywords: teachers' SES; teachers' job satisfaction; teachers morale; teachers organizational commitment; elementary schools 


\section{The effect of teachers' socioeconomic status on elementary schools' life in Indonesia: An empirical study in the elementary schools of Merauke district, Papua}

\section{Introduction}

Teachers are in the front line of education system and, therefore, they are always blamed as the main source of all the students' failure in achieving success (Joni, 1991). This blaming is of relevant since, at the time of visit, some teachers are busy enough to selling snacks and soft drink at the school canteen than working hard to improve knowledge and skills of teaching. Besides, in other occasions, we also see some of teachers are engaged in a small business of raising livestock and opening stall. These salient conditions motivate us to a more study on socioeconomic status (SES) with the specific view of teachers SES.

Teachers' SES is most commonly determined by combining their level of education, occupational status, and income. There are vary of studies have been conducted on SES (e.g. Majoribanks, 1996; Seyfried, 1998; McNeal, 2001; Jeynes, 2002; Bradley \& Corwyn, 2002; Hochschild, 2003; Eamon, 2005; Cutler, Lleras-Muney, \& Vogl, 2008; Memon, Joubis, Khurram \& , 2010; Ogunshola \& Adewale, 2012; Ahmad \& Khan, 2012; Ahmar \& Anwar, 2013; Azher, Nadeem, Naz, Perveen, \& Sameen, 2013; Kapinga, 2014, Werang, 2015). Unfortunately, most of them are not directly related to teachers' SES. Researchers seem to more focus only on the effort of investigating the effect of parental SES on child(ren)'s academic achievement or on family health than the effect of teachers' SES on school's life. Researchers likely to talk on how teachers should work with economically deprived children than on the obligation of governments to promote the well-being of economically stressed teachers.

It has long been recognized that being a teacher is a demanding and sometimes even exhausting profession (Keller, Chang, Becker, Goetz, \& Frenzel, 2014).Though it was not really reported in the existing literature, we do believe that there are so many teachers in low-income countries which are, from day to day, struggling with the obligation of guiding students to achieve success in one hand and of caring their own family in the other hand. Low-SES teachers are even entering the classroom with all the burdensome thoughts and feelings of how to care their sick family member, to rent housing, to pay electricity arrears, to meet child(ren)' need for school, and so on. To explore the effect of teachers' SES on school's life, we employed quantitative approach using survey design, which we explain briefly below.

\section{Related Literature}

\subsection{Socioeconomic status (SES)}

So far there is no universal agreement among experts about the concept of socioeconomic status (SES), and we think it will never be. According to Wikipedia; The Free Encyclopedia, SES is an economic and sociological combined total measure of a person's work experience and of an individual's or family's economic and social position in relation to others, based on income, education, and occupation. Similarly Burden and Byrd (1990 as cited in Werang, 2014, p. 436) defined SES as a measure of a family's relative position in a community, determined by a combination of income, occupation, and level of education. Meanwhile, Bradley and Corwyn (2002) viewed SES as a broad construct representing a family's access to social and economic resources, and most frequently assess using measures of family income, parents' educational level, and occupation. 
The effect of teachers' socioeconomic status on elementary schools' life in Indonesia

It is generally accepted that parental SES has an impact on school effectiveness and students' academic achievement alike. Ahmad and Khan (2012) argued,

The socioeconomic status is positively correlated with both educational and attainment and achievement. It can hypothetically state that the higher a student's parental socio-economic status, the greater his or her academic performance in secondary school is likely to be. In this hypothetical phrase, it has been observed that socio-economic condition is a cause, wich correlates with academic achievement effect (p. 139).

Otula (2007, as cited in Kapinga, 2014) finds that effective provision of secondary education is hampered by low parental SES due to that they are fail to afford children's basic needs for schools. Kapinga (2014) asserted that children from low SES family are "at higher risk than advantaged children for retention in their grades, special deleterious placement during the school's hours and even not completing their secondary school education" (p. 123). Children from low SES family even "do not have access to extra learning facilities, hence, the opportunity to get to the top of their educational ladder may not be very easy" (Becker \& Tomes, 1979 as cited in Ahmar \& Anwar, 2013, p. 13). In contrast, children from high and middle SES family are "better exposed to a learning environment at home because of provision and availability of extra learning facilities" (Ahmar \& Anwar, 2013, p. 13). Becker and Tomes (1979, as cited in Ahmar \& Anwar, 2013) asserted, "it has become well recognized that wealthy and well-educated parents ensure their children's future earning by providing them a favorable learning environment, better education, and good jobs" (p. 13).

SES used in this present study refers directly to teachers' SES. Teachers' SES is most commonly determined by combining their level of education, occupational status, and income. Eggen and Kauchak (2004) argued that parents' SES provides a sense of their standing in their community, how much flexibility they have in the community where they live or what they buy, and the educational opportunities their children have. In this context of view, Eggen and Kauchak (2004) regarded SES as one of the most powerful factor related to school life and performance.

In line with Eggen and Kauchak's (2004) arguments, we do believe of the power of teachers' SES in determining schools' life, in regards to teachers' job satisfaction, teachers' morale, and teachers' organizational commitment. Low SES teachers will not only fail to both provide their daily basic needs and ensuring a favorable learning environment for their child(ren) at home, but also fail to design the school programs and to evaluate students' work. Low SES teachers are often present in school as a very tired person due to an extra hard-work to earn money for the family needs.

\subsection{Teachers job satisfaction and teachers' SES}

Various definitions have been given to job satisfaction but, so far, there is no universal agreement on how it should be defined. Greenberg and Baron (1997) defined job satisfaction a positive or negative attitude of an employee toward his/her job. Meanwhile McShane (2004) defined job satisfaction as the individual's evaluation of his or her own work in terms of the context and content of the work, whereas, Kreitner and Kinicki (2007) viewed job satisfaction as an affective or emotional response on one's job aspect.

Spector (as cited in Werang, 2015, p. 27) identified three reasons to justify how important employees' satisfaction is. First, human values are essential in orienting the organization by respecting and treating their staff fairly, which in turn will reflect positively on their emotions and wellbeing. Second, the behavior of the organization's staff impact on its operations, either positively or negatively. Third, the assessment of employee's satisfaction is crucial in identifying the areas in need of improvement.

In educational context, Heller et al. (as cited in Gkolia, Belias, \& Koustelios, 2014) argued that schools should pay more attention to improve teacher job satisfaction. Zembylas and Papanastasiou (2004) viewed teachers' job satisfaction as all those feelings of satisfaction that teachers have in their job of teaching and lead 
Werang, B. R., Lewaherilla, E. D., \& Irianto, O.

them to be high committed and passionate. Teachers with high level of job satisfaction are able to manage the classroom more effectively and resolve school problems by retaining good interpersonal relations with students' parents, their colleagues and their principal (Gkolia et al., 2014).

Teachers' job satisfaction is closely link with teachers' SES. Based on the assumption that there are basic and universal human needs, Sousa-Poza and Sousa-Poza (2000 as cited in Cabrita \& Perista, 2006, p. 1) proposed, "If an individual' needs are fulfilled in their current situation then he or she will be happy. [...] satisfaction depends on the balance between work-role inputs- such as education, working time, effort- and work-role outputs-wages, fringe benefits, status, working conditions, intrinsic aspect of the job". This proposal leads us to hypothesize the following:

Hypothesis 1. Teachers' SES (the availability of family basic needs, the availability of learning facilities at home, and teachers' social position in his or her respective community) will significantly effect on teachers job satisfaction (pay, promotion, supervision, fringe benefits, contingent rewards, operating conditions, co-workers, the nature of the work, and communication) in elementary schools of Merauke district, Papua.

\subsection{Teachers morale and teachers'SES}

The American Heritage College Dictionary (2004, p. 904) defined morale as "the state of the spirits of a person or group as exhibited by confidence, cheerfulness, discipline, and willingness to perform assigned tasks". While Washington and Watson (1976, p. 3) defined morale as "the feeling a worker has about his job based on how the worker perceives himself in the organization and the extent to which the organization is viewed as meeting the worker's own needs and expectations". Whereas Bentley and Rempel (1980, p. 2) defined morale as "the professional interest and enthusiasm that a person displays toward the achievement of individual and group goals in a given job situation".

Getzel and Guba (1957 as cited in Houchard, 2005, p. 22) offered a theoretical model of morale which composed of three different elements, namely: (a) belongingness which refers to the teacher's ability to achieve satisfaction within his or her working group of the school; (b) rationality which deals with teacher's feeling of job appropriateness wherein the teacher's role is in line with the goals they are required to achieve for the schools, and (c) identification which refers to the teacher's to combine his or her needs and values with those of the school so that they are somewhat alike. Meanwhile Lipham et al. (1985 as cited in Houchard, 2005, p. 22) contended morale as comprised of the existence of and interaction between the three components, namely: (a) effectiveness: refers to how an individual's behavior fits with organizational's expectation: (b) efficiency: refers to how a group's social behavior is in-line with that of the individual's behavior; and (c) satisfaction: refers to how organizational's role expectations matches with the individual's need disposition.

Wentworth (1990) listed 13 essential factors that determine teacher's morale as follow: (1) decision-making input that directly affects curriculum, instruction, and school climate; (2) teacher's recognition and appreciation and student's achievement; (3) school climate that reflects a feeling of unity, pride, cooperation, acceptance of differences, and security among school's members; (4) good communication among school's members; (5) opportunities for teacher's meaningful professional growth; (6) clear and shared goals between teachers; (7) strong and supportive school principal's leadership; (8) quality time availability for principal and teachers interaction in planning, educational dialog, decision-making, and problem solving; (9) well-maintained school physical facilities and environment; (10) good relations both within school and between school and local community members; (11) encouragement and special reward for teachers in risk taking, innovation, and good teaching; (12) giving more attention to teacher's professional needs such as salary and benefits; and (13) paying specific attention to teacher's personal needs such as stress management, good health, and social interaction.

Teacher's morale can be low or high. Low morale is contagious and can plague the workplace by spreading from one teacher to the next (Sheahan, n/d). Wentworth (1990) referred teacher's professional lives that have little meaning, frustration, and teacher's inability to change what is happening as the main sources of low 
The effect of teachers' socioeconomic status on elementary schools' life in Indonesia

teachers morale. Low morale causes teachers to lose interest in doing the extra work. Low morale teachers exhibit a higher frequency of being absent from the workplace because they do not feel as committed to or as invested in their jobs (Sheahan, n/d). In contrast, high teacher's morale related to teacher's feelings of belongingness, togetherness, achievement, and self-and group-esteem (Clough, 1989 as cited in Houchard, 2005). Hoy and Miskel (1987 as cited in Houchard, 2005) asserted that when environment are healthy and teacher morale is high not only do teachers feel good about themselves and others but they also possess as sense of accomplishment from their jobs. Washington and Watson (1976, p. 4) listed the following characteristics of teachers with high morale as follow: (1) going to work in the early morning and were not leave the work before time; (2) paying concern to the direction to which the school and the program are moving; (3) participating actively in all the school's activities; (4) performing willingly various school jobs that were above and beyond their stated duties; (5) deriving satisfaction from being a member of the school, system, and teaching profession; (6) supporting the school's goals and philosophy; and (7) engaging actively in creating and improving school-community relationship.

Teachers' morale is closely link with teachers' SES. Sahertian (2000 as cited in Werang, 2015. p. 436) asserted that teachers with low SES present in schools as a very confused and chaotic person due to they were not able to provide yet daily basic needs. Similarly, Nichols (2006, as cited in Werang, 2015. p. 436) referred low-pay-high-cost-of-living gap as one of the factors influencing teacher's low morale. These arguments lead us to hypothesize the following:

Hypothesis 2. Teachers' SES (the availability of family basic needs, the availability of learning facilities at home, and teachers' social position in his or her respective community) will significantly effect on teachers morale (belongingness, rationality, and identification) in elementary schools of Merauke district, Papua, Indonesia.

The concept of organizational commitment has already received considerable attention from both theorists and practitioners. According to Meyer, Kam, Gildenberg, and Bremmer (2013), organizational commitment refers to the extent to which the employees of an organization see themselves as belonging to the organization (or parts of it) and feel attach to it; while Wolowska (2014) viewed organizational commitment as one of the basic concepts describing the relationship between an employee and an organization. Whereas Mowday, Steers, and Porter (1979) defined organizational commitment as: (a) a strong belief in and acceptance of the organizations' goals and values; (b) a willingness to exert considerable effort on behalf of the organization; and (c) a strong desire to maintain membership in organization.

\subsection{Teachers organizational commitment and teachers' SES}

Commitment will never happen unless the employees feel that they count for something. "Commitment grows when employees have a chance to contribute. Create a work environment where people can achieve, and you create a climate of a greater commitment" (Pritchett, 1994, p. 8). Meyer and Allen (1984) and Allen and Meyer (1990) developed their three component model of commitment as follows: First, affective commitment. Hall (1970) defined affective commitment as the process by which the goals of the organization and those of the individual become increasingly congruent. According to Meyer and Allen (1997), affective commitment refers to the employees' emotional attachment to, identification with, and involvement in the organization. Employees who are affectively committed to the organization will continue to work for the organization because they want to (Meyer \& Allen, 1991). In the words of Beck and Wilson (2000), employees who are committed on an affective level will always stay with the organization because they view their personal employment relationship as congruent to the goals and values of the organization.

Second, is continuance commitment. Meyer and Allen (1997, p. 11) defined continuance commitment as awareness of the costs associated with leaving the current organization. Beck and Wilson (2000) regarded continuance commitment as an instrumental attachment to the organization, where the individual association 
Werang, B. R., Lewaherilla, E. D., \& Irianto, O.

with the organization is based on assessment of economic benefits gained. While Hrebiniak and Alutto (1972, p. 556) viewed continuance commitment as a structural phenomenon, which occurs because of individualorganization transactions and altercations in side bets or investment over time.

Third, is normative commitment. Meyer and Allen (1997) defined normative commitment as a feeling of obligation to continue employment. While Wiener (1982, p. 421) viewed as the totality of internalized normative pressures to act in a way which meets organizational goals and interest. Whereas March and Mannari (1977, p. 59) regarded normative commitment as the commitment employees consider morally right to stay in the company, regardless of how much status enhancement or satisfaction the firm gives him or her over the years.

Teachers' organizational commitment is closely link with teachers' SES. Since SES is also composed of the level of income, salary or pay plays a fundamental role in attracting and motivating employees to be committed. Salary or pay refers to the amount of money and material that an employee receives for a particular job or function in an organization. In their study, Hom and Griffeth (1995) and Cohen-Charash and Spector (2001) revealed that pay satisfaction positively related to employee commitment. Similarly, Lumley, Coetzee, Tladinyane, and Ferreira (2011) found that pay satisfaction is significantly and positively related to affective and normative commitment. These findings lead us to hypothesize the following:

Hypothesis 3. Teachers' SES (the availability of family basic needs, the availability of learning facilities at home, and teachers' social position in his or her respective community) will significantly effect on teachers' organizational commitment (affective, continuance, and normative) in elementary schools of Merauke district, Papua, Indonesia.

Based on related literature examining the effect of teachers' SES on teachers' job satisfaction, teachers' morale, and teachers' organizational commitment, the analytical framework of this present study is as presented in Figure 1.

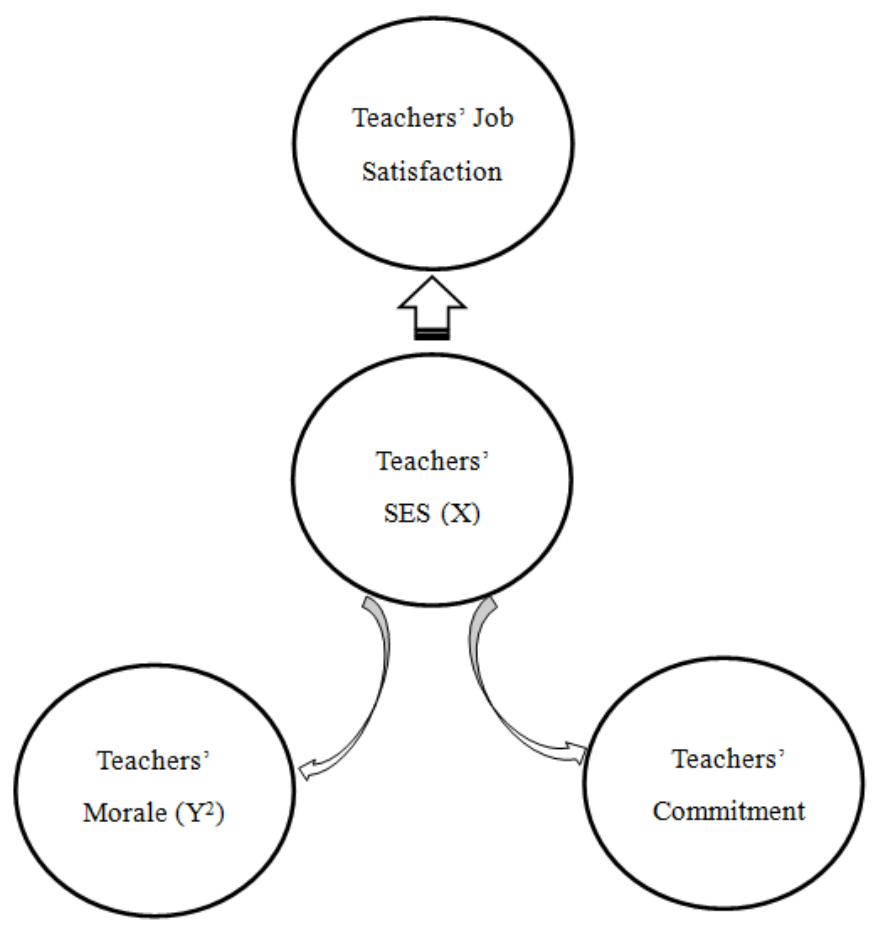

Figure 1. Analytical framework of the study 


\section{Method of the study}

\subsection{Study design and participants}

In order to better understand the manner in which teachers' SES impact on teachers job satisfaction, teachers morale, and teachers organizational commitment in elementary schools of Merauke district, we employed a quantitative approach using a survey design as it sought to establish the effect of teachers' SES on schools' life. We employed a survey design due to that: (a) high representativeness; (b) low cost; (c) convenient data gathering; (d) good statistical significance; (e) little researchers subjectivity; and (f) precise results.

Four quantitative questionnaires using Likert Scale was administered to 258 elementary schools' teachers of Merauke district who are samples/respondents, out of 1300. Samples were drawn purposively due to that: (a) limited research personnel; and (b) many teachers were not at schools at the time of data collection. Three null hypothesis examined in this study as follow: (a) teachers' SES has no significant effect on teachers job satisfaction in elementary schools of Merauke district, Papua, Indonesia; (b) teachers' SES has no significant effect on teachers' morale in elementary schools of Merauke district, Papua, Indonesia; and (c) teachers' SES has no significant effect on teachers organizational commitment in elementary schools of Merauke district, Papua, Indonesia.

\subsection{Measures}

Teacher's SES. Teachers' SES was measured by modifying Albatch, Amove, and Kelly (1982) and Woolfolk's (1993) descriptors into 26 positive statements which are distributed over three dimensions of SES (the availability of family basic needs, the availability of learning facilities at home, and teacher's social position in his or her respective community). The inventory used a four point scale ( $4=$ strongly agree and $1=$ strongly disagree). Respondents are requested to respond each statement on a scale of four alternatives, that are strongly agree (SA), agree (A), disagree (D) and strongly disagree (SD). Sample of items include "I am satisfy with the level of pay I receive", "Home where my family and I stay is our own", "my monthly salary is enough to pay electricity arrears", "my monthly salary is enough for child(ren)'s education", "My salary is enough to provide learning facilities at home", "I feel supported, valued, and appreciated by my community". We employed a Cronbach's alpha coeficient to test the internal reliability of this instrument. The reliability level of alpha of this present study was 0.78 .

Teachers' job satisfaction. Teachers job satisfaction was measured using the nine facet of job satisfaction (pay, promotion, supervision, fringe benefits, contingent rewards, operating conditions, co-workers, the nature of the work, and communication) established by Spector (1997). The inventory used a four point scale (4 = strongly agree and 1 = strongly disagree). Respondents are requested to respond each statement on a scale of four alternatives, that are strongly agree (SA), agree (A), disagree (D) and strongly disagree (SD). Sample of items include "I am satisfy with the level of pay I receive", "I feel encouraged to come up with new and better ways of doing things", "I have the tools and resources to do my job well", "My work of teaching gives me a feeling of personal accomplishment and pride", "I am valued by my principal", "I am rewarded for the quality of my efforts", "I experience personal growth such as updating skills of teaching", "I get on well with my co-teachers", "I am well informed about any changes within this school". We employed a Cronbach's alpha coefficient to test the internal reliability of this instrument. The reliability level of alpha of this present study was 0.85 .

Teachers' morale. Teachers morale was measured using the three facet of morale (belongingness, rationality, and identification) established by Getzel and Guba (1957 as cited in Houchard, 2005). The inventory used a four point scale ( $4=$ strongly agree and $1=$ strongly disagree). Respondents are requested to respond each statement on a scale of four alternatives, that are strongly agree (SA), agree (A), disagree (D) and strongly disagree (SD). Sample of items include "I go to work early morning and do not leave the work before time", "My work of teaching gives me a feeling of personal accomplishment and pride", "The duties of my position are clearly 
Werang, B. R., Lewaherilla, E. D., \& Irianto, O.

defined", "I really feel as if this school's problems are my own", "I am able to get easy access to my principal", "My work of teaching makes good use of my skills and abilities", and "I feel supported, valued, and appreciated by my principal". We employed a Cronbach's alpha coeficient to test the internal reliability of this instrument. The reliability level of alpha of this present study was 0.82 .

Teachers' organizational commitment. Teachers' organizational commitment was measured using the three-dimensional Meyer, Allen, and Smith (1993) instrument originally developed by Allen and Meyer (1990). The affective, continuance, and normative organizational commitment scales each comprised 5 items, modified from the original questionnaire consisting of 24 items. The inventory uses a four point scale $(4=$ strongly agree and $1=$ strongly disagree). Respondents are requested to respond each statement on a scale of four alternatives, that are strongly agree (SA), agree (A), disagree (D) and strongly disagree (SD). Sample items include "I would be very happy to spend the rest of my career with this profession", "It would be very hard for me to leave my profession right now, even if I wanted to", "Right now, staying with my profession is a matter of necessity as much as desire", "One of the major reasons I continue to work in this profession is that I believe loyalty is important and therefore feel a sense of moral obligation to remain", and "I was taught to believe the value of remaining loyal to one profession". We employed a Cronbach's alpha coeficient to test the internal reliability of this instrument. The reliability level of alpha of this present study was 0.90 .

\section{Results of the study}

The study aims to describe the effect of teachers' SES on schools' life, in regards to school teachers' job satisfaction, teachers' morale, and teachers' organizational commitment. In order to have an accurate results of data analysis, we employed software of the Statistical Package for the Social Sciences (SPSS) program version 16 for Windows. The results of analysis are reflected in Table 1.

\section{Table 1}

Results of data analysis

\begin{tabular}{|c|c|c|c|c|c|c|}
\hline \multicolumn{7}{|c|}{ Tests of between-subjects effects } \\
\hline Source & Dependent Variable & $\begin{array}{c}\text { Type III Sum of } \\
\text { Squares }\end{array}$ & df & Mean Square & $\mathrm{F}$ & Sig. \\
\hline \multirow[t]{3}{*}{ Corrected Model } & Teacher job satisfaction & $4062.76^{\mathrm{a}}$ & 16 & 253.92 & 22.86 & .000 \\
\hline & Teacher morale & $2287.36^{\mathrm{b}}$ & 16 & 142.96 & 4.19 & .000 \\
\hline & Organizational commitment & $1416.49^{c}$ & 16 & 88.53 & 12.85 & .000 \\
\hline \multirow[t]{3}{*}{ Intercept } & Teacher job satisfaction & 1593871.35 & 1 & 1593871.35 & 1.44 & .000 \\
\hline & Teacher morale & 734446.28 & 1 & 734446.28 & 2.15 & .000 \\
\hline & Organizational commitment & 505527.57 & 1 & 505527.57 & 7.34 & .000 \\
\hline \multirow[t]{3}{*}{ Teacher SES } & Teacher job satisfaction & 4062.76 & 16 & 253.92 & 22.86 & .000 \\
\hline & teacher morale & 2287.36 & 16 & 142.96 & 4.19 & .000 \\
\hline & Organizational commitment & 1416.49 & 16 & 88.53 & 12.85 & .000 \\
\hline \multirow[t]{3}{*}{ Error } & Teacher job satisfaction & 2676.75 & 241 & 11.11 & & \\
\hline & Teacher morale & 8230.33 & 241 & 34.15 & & \\
\hline & Organizational commitment & 1659.79 & 241 & 6.89 & & \\
\hline \multirow[t]{3}{*}{ Total } & Teacher job satisfaction & 2445721.00 & 258 & & & \\
\hline & Teacher morale & 1127907.00 & 258 & & & \\
\hline & Organizational commitment & 765808.00 & 258 & & & \\
\hline \multirow[t]{3}{*}{ Corrected Total } & Teacher job satisfaction & 6739.51 & 257 & & & \\
\hline & Teacher morale & 10517.69 & 257 & & & \\
\hline & Organizational commitment & 3076.28 & 257 & & & \\
\hline
\end{tabular}

Note. a. R Squared $=.603$ (Adjusted R Squared $=.576)$, b. R Squared $=.217$ (Adjusted R Squared $=.166)$, c. R Squared $=.460$ (Adjusted R Squared $=.425)$, d. Computed using alpha $=0.05$ 
Based on the results of data analysis as they are presented in Table 1, empirical model of the effect of teachers' SES on the schools' life in elementary schools of Merauke district is as reflected in Figure 2.

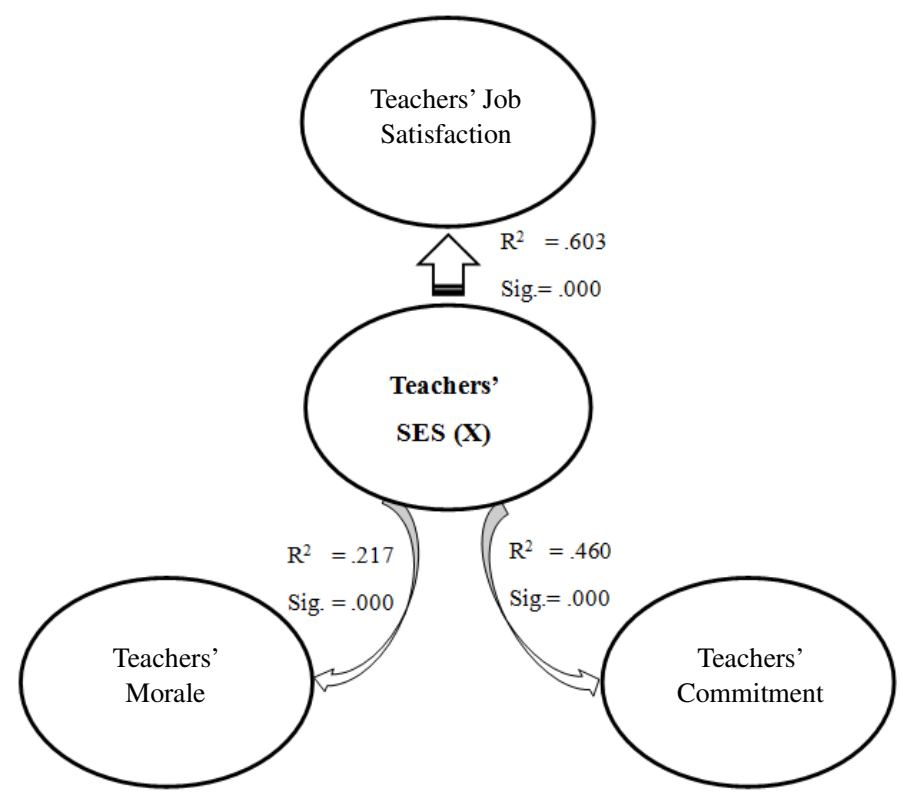

Figure 2. Empirical model of the study

The results of data analysis as they are reflected in Figure 2 show that:

$>\quad$ Teachers' SES has a significant effect on teachers' job satisfaction as the $\mathrm{R}^{2}$ value of 0.603 is significant at $\mathrm{p}=0.000(\alpha=0.05)$. As the significant value ( $p$-value) is less than $5 \%$, our research hypothesis that teachers' SES (the availability of family basic needs, the availability of learning facilities at home, and teachers' social position in his or her respective community) will significantly effect on teachers' job satisfaction (pay, promotion, supervision, fringe benefits, contingent rewards, operating conditions, co-workers, the nature of the work, and communication) is accepted. In other words, at the alpha $(\alpha)$ 's level of 0.05 , the null hypothesis that teachers' SES has no significant effect on teachers' job satisfaction in elementary schools of Merauke district, Papua, Indonesia, is rejected.

$>$ Teachers' SES has a significant effect on teachers' morale as the $\mathrm{R}^{2}$ value of 0.217 is significant at $\mathrm{p}=$ $0.000(\alpha=0.05)$. As the significant value ( $p$-value) is less than $5 \%$, our research hypothesis that teachers' SES (the availability of family basic needs, the availability of learning facilities at home, and teachers' social position in his or her respective community) will significantly effect on teachers' morale (belongingness, rationality, and identification) is accepted. In other words, at the alpha $(\alpha)$ 's level of 0.05 , the null hypotheses that teachers' SES has no significant effect on teachers' morale in elementary schools of Merauke district, Papua, Indonesia, is rejected.

$>\quad$ Teachers' SES has a significant effect on teachers' organizational commitment as the $\mathrm{R}^{2}$ value of 0.460 is significant at $\mathrm{p}=0.000(\alpha=0.05)$. As the significant value ( $p$-value) is less than $5 \%$, our research hypothesis that teachers' SES (the availability of family basic needs, the availability of learning facilities at home, and teachers' social position in his or her respective community) will significantly effect on teachers' organizational commitment (affective, continuance, normative) is accepted. In other words, at the alpha $(\alpha)$ 's level of 0.05 , the null hypotheses that teachers' SES has no significant effect on teachers' organizational commitment in elementary schools of Merauke district, Papua, Indonesia, is rejected. 


\section{Discussion}

Teachers are always 'a boon to society' (Chamundeswari, 2013, p. 420) and are respected as knowledgeable about different subjects of school (Werang et al., 2014). Teachers are even regarded as "gatekeepers to knowledge and mentors with an important role in character development of children, future productive citizens to contribute to the broader wellbeing of a society" (Uehara, 1999; Suparno, 2008; Alma, 2008, cited in Uncen-Unipa-Smeru-BPS-Unicef, 2012, p. 22). Teachers are entrusted with the responsibility to educate the future leaders of tomorrow and are essential to students' achievement (Murphy et al. as cited in Koenig, 2014, p. 1). Teachers are even expected to successfully perform many different roles and responsibilities in their work, such as being a motivator, observer, counsellor, manager, school leader, resource provider, mentor for fellow teachers, and an active agent of change for themselves and their students (Cohen et al., 1996 and Harrison \& Killion, 2007 as cited in Koenig, 2014, p. 1).

As teachers' life and work is dedicated to develop and improve the knowledge, skills, and characters of new generation of nations, this present study focuses on how teachers' SES effects the school's life aspects. Results of data analysis show that teachers' SES has a positive significant effect on school's life, in regards to teachers' job satisfaction, teachers' morale, and teachers' organizational commitment in the elementary schools of Merauke district, Papua, Indonesia. This finding demonstrates that changes one point in independent variable (teachers' SES) would strongly effect on dependent variables (teachers; job satisfaction, teachers; morale, and teachers; organizational commitment). In other words, as the value of $\mathrm{R}^{2}$ is positive and significant, it shows that when the research variable 'teachers' SES' increases or decreases then the research variable 'teachers job satisfaction', 'teachers morale', and 'teachers organizational commitment' would also increases or decreases.

Given the pivotal role of teachers in developing knowledge, skills and character, teachers' job performance inside and outside of the classroom is of important. Abundant roles and responsibilities that teachers have to perform show us of how stressful the teaching profession is (Kyriacou \& Sutcliffe, 1977; Johnson, Cooper, Cartwright, Donald, Taylor, \& Millet, 2005). Among other causes, such as role conflict and ambiguity (Dunham, 1992), time pressure (Chan, 1998), student misbehavior (Turk, Meeks, \& Turk, 1982), relationships with supervisors (Litt \& Turk, 1985), and large class size (Burke \& Greenglass, 1994), we do believe the most frequently cause responsible for teachers stress and job dissatisfaction in the elementary schools of Merauke district is inadequate salary and perceived low status (Carlson \& Thompson, 1995; Kyriacou \& Sutcliffe, 1978).

Teachers' salary and incentives which is rates of IDR 1,500.000 up to IDR 17,500,000 (equivalent to US $\$ 125$ up to $\$ 1,250$ ) per month seem to be less than enough to afford all the family basic needs, especially those whose salary and incentives is under IDR 3,500,000 (equivalent to US \$ 310) per month with the total family member is 4 above. Teachers are still men or women who, just like others, "have a multiplicity of needs, psycical, emotional, and spiritual" (Baldoni, 2005, p. 33). As men or women, teachers likely to feel more fit and enjoy in a SES of which their needs are adequately met both physical and psychological, and socio-cultural. Just like other families, teachers are obliged to provide all the family basic needs, such meal, clothing, housing, electricity, health, child(ren)'s education, spiritual and social-cultural activities. Independent of how society percept the life of teachers, but our own experience shows of that matter.

High-SES teachers value and emphasize autonomy and individual responsibility (Machionis, 2000 as cited in Eggen \& Kauchak, 2004, p. 131). High-SES teachers have more times at home to prepare teaching-learning materials and media, checking, and evaluating students' work. High-SES teachers are able to provide both family basic needs and adequate learning facilities at home to improve their own capabilities of teaching and to enhance child(ren)'s knowledge and skills (Albatch et al., 1982; Woolfolk, 1993). They have high expectations for their child(ren) and encourage them to attend the college (Trusty \& Firtle, 1998 as cited in Eggen \& Kauchak, 2004, p. 131).

Low-SES teachers, in contrast, place greater emphasis on conformity and obedience (Machionis, 2000 as 
The effect of teachers' socioeconomic status on elementary schools' life in Indonesia

cited in Eggen \& Kauchak, 2004, p. 131). Low-SES teachers do not have enough time at home to design school's programs, to prepare teaching-learning material and media, and to evaluate students' work. Low-SES teachers are even not able to provide both family basic needs and adequate learning facilities at home to regularly improve their knowledge and skills to deal with the challenges of today's world. In order to afford all the family basic needs, elementary schools' teachers of Merauke district sometimes in home have to deal with an extra work, such as farming, raising livestock, and opening stall.

Low-SES teachers are sometimes entering the classroom with all the burdensome thoughts and feelings of how to caring their sick family member, to rent housing, to pay electricity arrears, to meet child(ren)'s need for school, and so on. They looked somehow too tired and exhausted. This fact can directly impact on teacher's work of teaching and relations at school. Instead of teaching students to achieve success, many of elementary schools' teachers in Merauke city leave the classrooms for school's canteen juts to make sure that their selling materials are sold out. Similarly, remote elementary schools' teachers have even been leaving the schools for a long period of time (Werang et al., 2016, in press) to deal with more earning activities. These findings are in-line with Nichol's and Sahertian's (as cited in Werang, 2015), Sousa-Poza \& Sousa-Poza's (2000 as cited in Cabrita \& Perista, 2006, p. 1), Hom and Griffeth (1995), Cohen-Charash snd Spector (2001), and Lumley et al. (2011) findings.

\section{Conclusion, implications, and recommendation}

Based on the data analysis which have already discussed, the conclusions depicted from the results of the study are follows:

$>\quad$ Teacher SES has a positive significant effect on teachers' job satisfaction in elementary schools of Merauke district, Papua, Indonesia. It is indicated by the $\mathrm{R}^{2}$ value of 0.603 is significant at $p=0.000$. It means that teachers' job satisfaction in elementary schools of Merauke district is of $60.3 \%$ explained by teacher SES, while the rest of $39.7 \%$ is explained by other research variables which are not the focus of this present study.

$>\quad$ Teacher SES has a positive significant effect on teachers' morale in elementary schools of Merauke district, Indonesia. It is indicated by the $\mathrm{R}^{2}$ value of 0.217 is significant at $p=0.000$. It means that teachers' morale in elementary schools of Merauke district is of $21.7 \%$ explained by teacher SES, while the rest of $78.3 \%$ is explained by other research variables which are not the focus of this present study.

$>\quad$ Teacher SES has a positive significant effect on teachers' organizational commitment in elementary schools of Merauke district, Papua, Indonesia. It is indicated by the $\mathrm{R}^{2}$ value of 0.460 is significant at $p=0.000$. It means that teachers' organizational commitment in elementary schools of Merauke district is of $46 \%$ explained by teacher SES, while the rest of $54 \%$ is explained by other research variables which are not the focus of this present study.

$>\quad$ Practical implication of our findings is that school supervisors and The Head of Educational Office at government level should be sure that teacher SES is at high level in order that school teachers' job satisfaction, teachers' morale, and teachers' organizational commitment would be met adequately. These findings might be worthwhile for the government, especially government from the low-income countries, to pay more attention and to make an effort of creating different programs to enhance teachers' SES.

$>\quad$ Result of this study provides a closer look on the effect of teachers' SES on school's life, with regards to teachers' job satisfaction, teachers' morale, and teachers' organizational commitment in the elementary schools of Merauke district, Papua, Indonesia. Since empirical studies investigating the effect of teachers' SES on school's life is still very lack, findings of this present study may 
Werang, B. R., Lewaherilla, E. D., \& Irianto, O.

theoretically add the existing literatures on parents' SES in general and specially on teachers' SES.

$>\quad$ Our present study is limited on the effort of investigating the effect of teachers' SES on teachers' job satisfaction, teachers' morale, and teachers' organizational commitment. Therefore, a more study on the role of teachers' SES as predicting factor for the school's life aspects would be fully recommended. In other words, it is imperative for the future researchers to elaborate more the effect of teachers' SES on schools' life aspects, such as teachers' burnout, teachers' engagement, and students' academic achievement.

\section{References}

Ahmad, I., \& Khan, N. (2012). Relationship between parental socioeconomic conditions and students' academic achievements: A case of district dir. Timergara, Pakistan. Global Advance Research Journal of Educational Research and Review, 1(7), 137-142.

Ahmar, F., \& Anwar, E. (2013). Socioeconomic status and its relation to academic achievement of higher secondary school student. IOSR Journal of Humanities and Social Science, 13(6), 13-20. https://doi.org/10.9790/0837-1361320

Albatch, P. G., Amove, R. F., \& Kelly, G. P. (1982). Comparative education. New York: McMillan Publishing Co, Inc.

Allen, N. J., \& Meyer, J. P. (1990). The measurement and antecedants of affective, continuance, and normative commitment to the organization. Journal of Occupational Psychology, 63, 1-18. https://doi.org/10.1111/j.2044-8325.1990.tb00506.x

American heritage college dictionary. (4th edition). (2004). Boston: Houghton Mifflin.

Azher, M., Nadeem, S., Naz, F., Perveen, F., \& Sameen, A. (2013). Impact of parental education and socio-economic status on academic achievements of university students. International Journal of Academic Research and Reflection, 1(3), 25-33.

Baldoni, J. (2005). Great motivation secrets of great leaders. New York: McGraw Hill

Beck, N. M., \& Wilson, J. H. (2000). Development of affective organizational commitment: A cross-sequential examination of change with tenure. Journal of Vocational Behaviour, 56, 114-136. https://doi.org/10.1006/jvbe.1999.1712

Bentley, R. R., \& Remple, A. M. (1980). Manual for the Purdue teacher opinionaire. West Lafayette, IN: Purdue Research Foundation.

Bradley, R. H., \& Corwyn, R. F. (2002). Socioeconomic status and child development. Annual Review of Psychology, 53, 371-379. https://doi.org/10.1146/annurev.psych.53.100901.135233

Burke, R. J., \& Greenglass, E. R. (1994). Towards understanding of work satisfactions and emotional well-being of school-based educators. Stress Medicine, 10, 177-184. https://doi.org/10.1002/smi.2460100307

Carlson, B. C., \& Thompson, I. A. (1995). Job burnout and job leaving in public school teacher: Implication for stress management. International Journal of Stress Management, 2, 15-20. https://doi.org/10.1007/BF01701948

Chamundeswari, S. (2013). Job satisfaction and performance of school teachers. International Journal of Academic Research in Business and Social Sciences, 3(5), 420-428.

Chan, D. W. (1998). Stress, copying strategies, and psychological distress among secondary school teachers in Hong Kong. American Educational Research Journal, 35, 145-163. https://doi.org/10.3102/00028312035001145

Cohen-Charash, Y., \& Spector, P. E. (2001). The role of justice in organizations: A meta-analysis. Organizational Behavior and Human Decision Processes, 86(2), 278-321. https://doi.org/10.1006/obhd.2001.2958

Cutler, D. M., Lleras-Muney, A., \& Vogl, T. (2008). Socioeconomic status and health: Dimension and mechanism. https://doi.org/10.3386/w14333

Dunham, J. (Ed.). (1992). Stress in the workplace: Past, present, and future. Philadelphia, PA: Whurr Publishers, Ltd. 
The effect of teachers' socioeconomic status on elementary schools' life in Indonesia

Eamon, M. K. (2005). Social-demographic, school, neighborhood, and parenting influences on academic achievement of Latino young adolescents. Journal of Youth and Adolescence, 34(2), 163-175. https://doi.org/10.1007/s10964-005-3214-X

Eggen, P., \& Kauchak, D. (2004). Educational psychology: Windows on classroom. NJ: Prentice Hall.

Gkolia, A., Belias, D., \& Koustelios, A. (2014). Teachers' job satisfaction and self-efficacy: A review. European Scientific Journal, 10(22), 321-342.

Greenberg, J., \& Baron, R. A. (1997). Behavior in organization (6 ${ }^{\text {th }}$ edition). Englewood Cliffs, NJ: Prentice-Hall.

Hall, K. (1970). An r-dimensional quadratic placement algorithm. Management Science, 17(3), 219-229. https://doi.org/10.1287/mnsc.17.3.219

Hochschild, J. L. (2003). Social class in public schools. Journal of Social Issues, 59(4), 821-840. https://doi.org/10.1046/j.0022-4537.2003.00092.x

Hom, P. W., \& Griffeth, R. W. (1995). Employee turnover. Cincinnati, OH: South Western.

Houchard, M. A. (2005). Principal leadership, teacher morale, and student achievement in seven schools in Mitchell County, North Caroline. A dissertation presented to the Faculty of the Department of Educational Leadership and Policies Analysis. East Tennessee State University.

Hrebiniak, L. G., \& Alutto, J. A. (1972). Personal and role-related factors in the development of organizational commitment. Administrative Science Quarterly, 17(4), 555-572. https://doi.org/10.2307/2393833

Jeynes, W. H. (2002). Examining the effects of parental absence on the academic achievement of adolescent: the challenge of controlling for family income. Journal of Family and Economic Issues, 23(2), 189-210. https://doi.org/10.1023/A:1015790701554

Johnson, S., Cooper, C. L., Cartwright, S., Donald, I., Taylor, P., \& Millet, C. (2005). The experience of work-related stress across occupations. Journal of Managerial Psychology, 20, 179-187. https://doi.org/10.1108/02683940510579803

Joni. T. R. (1991). The main ideas on teacher education. Creating strategies for national development in 21 st century [Pokok-pokok pikiran mengenai pendidikan guru. Mencari strategi pembangunan nasional menjelang abad XXI]. Jakarta: Grasindo.

Kapinga, O. S. (2014). The impact of parental socioeconomic status on students' academic achievement in secondary schools in Tanzania. International Journal of Education, 6(4), 120-132. https://doi.org/10.5296/ije.v6i4.6420

Keller, M. M., Chang, M.-L., Becker, E. S., Goetz, T., \& Frenzel, A. C. (2014). Teachers' emotional experiences and exhaustion as predictors of emotional labor in the classroom: An experience sampling study. Frontiers in Psychology, 5. https://doi.org/10.3389/fpsyg.2014.01442

Koenig, A. (2014). Learning to prevent burning and fatigue: Teacher burnout and compassion fatigue. Electronic Thesis and Dissertation Repository, Paper 1928.

Kreitner, R., \& Kinicki, A. (2007). Organizational behavior ( $6^{\text {th }}$ edition). New York: McGraw-Hill.

Kyriacou, C., \& Sutcliffe, I. (1977). Teacher stress: A review. Educational Review, 29, 299-306. https://doi.org/10.1080/0013191770290407

Kyriacou, C., \& Sutcliffe, I. (1978). Teacher stress: Prevalence, sources, and symptoms. British Journal of Educational Psychology, 48, 159-167. https://doi.org/10.1111/j.2044-8279.1978.tb02381.x

Litt, M. D., \& Turk, D. C. (1985). Sources of stress and dissatisfaction in experienced high school teachers. Journal of Educational Research, 78, 178-185. https://doi.org/10.1080/00220671.1985.10885596

Lumley, E. J., Coetzee, M., Tladinyane, R., \& Ferreira, N. (2011). Exploring the job satisfaction and organizational commitment of employees in the information technology environment. Southern Africa Business Review, 15(1), 100-118.

Majoribanks, K. (1996). Family learning environments and students' outcomes: A review. Journal of Comparative Family Studies, 27(2), 373-394.

March, R., \& Mannari, H. (1977). Organizational commitment and turnover: A prediction study. Administrative Science Quarterly, 22, 57-67. https://doi.org/10.2307/2391746

McNeal, R. B. (2001). Differential effects of parental involvement on cognitive and behavioral outcomes by socioeconomic status. Journal of Socio-Economics, 30(2), 171-179. 
Werang, B. R., Lewaherilla, E. D., \& Irianto, O.

https://doi.org/10.1016/S1053-5357(00)00100-1

McShane, S. L. (2004). Canadian organizational behavior ( $5^{\text {th }}$ edition). Toronto: McGraw-Hill.

Memon, G. R., Joubis, M. F., \& Khurram, M. A. (2010). Impact of parental socio-economic status on students' educational achievement at secondary schools of district Malir, Karachi. Middle-East Journal of Scientific Research, 6(6), 678-687.

Meyer, J. P., \& Allen, N. J. (1984). Testing the side-bet theory of organizational commitment: Some methodological considerations. Journal of Applied Psychology, 69, 372-378. https://doi.org/10.1037/0021-9010.69.3.372

Meyer, J. P., \& Allen, N. J. (1991). A three component conceptualization of organizational commitment. Human Resources Management Review, 1, 61-89. https://doi.org/10.1016/1053-4822(91)90011-Z

Meyer, J. P., \& Allen, N. J. (1997). Commitment in the workplace. Theory, research, and application. California: Sage.

Meyer, J. P., Allen, N. J., \& Smith, C. (1993). Commitment to organization and occupations: Extension and test of a three-component conceptualization. Journal of Applied Psychology, 78(4), 538-551. https://doi.org/10.1037/0021-9010.78.4.538

Meyer, J. P., Kam, C., Gildenberg, I., \& Bremmer, N. L. (2013). Organizational commitment in the military: Application of a profile approach. Military Psychology, 25, 381-401. https://doi.org/10.1037/mil0000007

Mowday, R. T., Steers, R. M., \& Porter, L. W. (1979). The measurement of organizational commitment. Journal of Vocational Behavior, 14, 224-227. https://doi.org/10.1016/0001-8791(79)90072-1

Ogunshola, F., \& Adewale, A. M. (2012). The effects of parental socio-economic status on academic performance of students in selected schools in Edu Lga of Kawara State Nigeria. International Journal of Academic Research in Business and Social Sciences, 2(7), 230-239.

Pritchett, P. (1994). Firing up commitment during organizational change. Dallas, TX: Pritchett and Associates, Inc.

Seyfried, S. F. (1998). Academic achievement of African American preadolescents: The influence of teacher perception. American Journal of Community Psychology, 26(3), 381-402.

https://doi.org/10.1023/A:1022107120472

Sheahan, $\mathrm{K} .(\mathrm{n} / \mathrm{d})$. The effect of low employee morale. Retrieved from http://www.ehow.com/list_6523648_effects-low-employee-morale.html

Turk, D. C., Meeks, S., \& Turk, L. M. (1982). Factors contributing to teachers stress: Implications for research, prevention, and remediation. Behavioral Counseling Quarterly, 2, 1-26.

Uncen-Unipa-Smeru-BPS-Unicef. (2012). 'We like being taught'. A study on teacher absenteeism in Papua and West Pариа. Retrieved from

https://www.google.co.id/?gws_rd=cr,ssl\&ei=IKxsVsrdF8ekuQSU5JXYBA\#q=we+like+being+taught+ a+study+on+teacher+absenteeism+in+papua+and+west+papua

Washington, R., \& Watson, H. F. (1976). Positive teacher morale: The principal's responsibility. NASSP Bulletin, 60, 4-6. https://doi.org/10.1177/019263657606039902

Wentwhort, M. (1990). Developing staff morale. The Practitioner, 16(4).

Werang, B. R. (2014). Teachers' socioeconomic status and its relationship with teachers' work morale and teachers' job performance at State Senior High Schools in Merauke Regency, Indonesia. International Journal of Science and Research, 3(8), 436-440.

Werang, B. R. (2015). A study of relationships in Christian Primary Schools of Boven Digoel Regency, Papua, Indonesia. The International Journal of Educational Organization and Leadership, 22(2), 24-33. https://doi.org/10.18848/2329-1656/CGP/v22i02/48502

Werang, B.R., Radja Leba, S. M., \& Pure, E. A. G. (2016). Factors influencing teachers absenteeism in the remote elementary schools of Indonesia: Empirical proof from Southern Papua. International Journal of Management in Education, in press.

Wiener, Y. (1982). Commitment in organizations. A normative view. Academy of Management Review, 7(3), 418-428. 
The effect of teachers' socioeconomic status on elementary schools' life in Indonesia

Wikipedia, The Free Encyclopedia. (n/d). Socioeconomic Status. Retrieved from https://en.wikipedia.org/wiki/Socioeconomic_status

Wolowska, A. (2014). Determinants of organizational commitment. Human Resources Management and Ergonomics, 8(1), 129-146.

Woolfolk, A. E. (1993). Educational Psychology. Boston: Allyn and Bacon.

Zembylas, M. \& Papanastasiou, E. (20004). Job satisfaction among school teachers in Cyprus. Journal of Educational Administration, 42(3), 357-374. https://doi.org/10.1108/09578230410534676 
Werang, B. R., Lewaherilla, E. D., \& Irianto, O. 